Article

\title{
Examining Trust and Risk in Mobile Money Acceptance in Uganda
}

\author{
Ronald Baganzi (1) and Antonio K. W. Lau * \\ School of Management, Kyung Hee University, Seoul 130-701, Korea; rbaganzi007@khu.ac.kr \\ * Correspondence: antoniolau@khu.ac.kr; Tel.: +82-2-961-9376
}

Received: 30 October 2017; Accepted: 1 December 2017; Published: 3 December 2017

\begin{abstract}
Mobile money adoption can contribute to achieving Sustainable Development Goals in Uganda but the factors affecting its sustainable adoption remain largely unknown. This paper explores the extent to which mobile money users' trust and risk perceptions affect mobile money services adoption of in Uganda. A survey was conducted with 438 mobile money users from Uganda and data was analyzed using Partial Least Squares (PLS) Structural Equation Modelling (SEM). From the results, we obtained new empirical evidence for applying trust and risk perceptions for analyzing mobile money acceptance. We found that mobile money users rely on the structural soundness of mobile money services providers and their ability to provide mobile money services with low perceived risk. Performance expectancy, perceived risk and structural assurance significantly influenced behavioral intention to adopt mobile money. Trust belief did not significantly influence behavioral intention. These results help us to understand and promote mobile banking services in underdeveloped countries, which is of practical and scientific interests. We finally provide practical implications for mobile money services providers, commercial banks and central banks in Africa.
\end{abstract}

Keywords: mobile money; sustainable adoption; trust; risk; self-efficacy; mobile money users; Uganda

\section{Introduction}

In 2015, Sustainable Development Goals (SDGs) were adopted by member states of the United Nations (UN) to: fight injustice and inequality, end poverty and combat climate change by 2030 [1] (p. 4). To achieve SDGs, mobile technology is essential because it provides a platform for improving social and economic development, as it provides access to applications that address social challenges faced by vulnerable people and enables new innovations [2] (p. 1) for building societies that are environmentally sustainable [1] (p. 4). The mobile industry has made significant progress against SDGs through increased connectivity and information access by enabling mobile money to contribute to productivity and poverty eradication [1] (p. 4). Sending and receiving monetary value is possible using mobile money transfer on the mobile phone [3,4]. This has resulted in mobile money users' convenience and flexibility as they are able to transact anytime, anywhere [5-7]. However, the growth of mobile money innovations comes with concern over security and risks [8,9]. As mobile money services continue to gain widespread consumer adoption, there is a growing concern about the risk and trust in the application $[8,10]$. We, therefore, posit that mobile money users' risk and trust perceptions may influence the acceptance of mobile money services $[7,9,11]$. On the other hand, much as some researchers have picked serious interest in studying the acceptance of information technology (IT) applications [12-14], a few scholars have researched on mobile money adoption in poor countries $[2,7,11,15,16]$. Therefore, the dearth of research on understanding implications of trust and risk on the acceptance of mobile money in Uganda makes it worthwhile to study.

Uganda is one of the countries in East Africa, a region that has been at the forefront of mobile money revolution in Africa in the past six years [17]. It is anticipated that the financial services sector 
will be transformed in the coming decades by information technologies, especially mobile money [17]. Mobile money transactions across borders will be more relevant than today because of the East African Common Market, which will enable free services trading [18]. Mobile money transfer is an IT-driven development that has had a positive impact on financial inclusion of poor citizens $[2,7,15,16]$ and has helped central banks from a regulatory point of view [16,19]. Achieving financial inclusion is a big step towards attaining sustainable economic development in poor countries [1,6]. Mobile money has transformed accessibility to financial services in East Africa [19]. It has improved welfare of people by positively impacting on household income [2]. Remittances received contribute to income directly, thereby reducing risk and liquidity constraints [2]. This has promoted agricultural commercialization, rural development and poverty reduction [2]. The number of people with mobile money accounts far exceeds those with bank accounts in East Africa [17]. Registered mobile money users in Uganda increased from 17.9 Million to 19.8 Million between 2014 and 2015, as accounts in banks remained at 5 Million [20]. However, this growing adoption of mobile money raises consumer protection concerns [10]. These include agent fraud; inappropriate disclosure of charges; system downtime; and agent liquidity issues [10]. The rate of mobile money adoption in East African countries also differs [11]. For example, Kenya has a higher adoption rate than Uganda or Tanzania [2]. It is noted that while M-Pesa (M stands for mobile; Pesa refers to money in Swahili [2,4]) has accelerated financial inclusion to millions of unbanked Kenyans, Uganda lags behind in its mobile money adoption rate [2].

Therefore, since it is unclear how Ugandan mobile money users perceive the technology application, the objective of our study is to contribute to the mobile money literature on exploring the risk and trust perceptions associated with the acceptance of mobile money services in Uganda. We develop a model for explaining how trust plays a critical role in users' behavioral intention to adopt mobile money services. We posit that mobile money users' risk perception should be studied alongside trust in mobile money applications. We, therefore, ask the research question: How do trust and risk perceptions of Ugandan mobile money users influence the sustainable adoption of mobile money? We specifically examine three personal trait constructs like self-efficacy, trust belief and structural assurance [21]. Kim et al. [22] found perceived risk to have an impact on behavioral intention towards e-payments systems, so we use perceived risk as a construct to study mobile money adoption. In practices, this study will help mobile money services providers, commercial banks and central banks to understand how mobile money users would perceive mobile money application. This will enable them to assess trust and reduce risk perceptions towards its eventual sustainable adoption. Central banks may use this research result to improve their public policies like mobile money customer protection. Analysis of mobile money usage, which is a substitute for some banking services, may also help commercial banks come up with counter-measures for retaining customers. The mobile money services providers can also refer to this study for developing strategies for mass adoption.

In the next part of this paper, we review mobile money adoption related literature, followed by a discussion of the conceptual framework and hypotheses development. These are followed by the research methodology, which involves data analysis using SmartPLS 2.0M3 structural equation modelling (SEM). We conclude the study with discussions of the results, contributions, limitations and future study suggestions.

\section{Literature Review}

We review the mobile money technological developments and discuss prior studies related to mobile money services adoption in East Africa. We point out the best examples of mobile money, which are M-Pesa and Mobile Telephone Networks (MTN) mobile money. The two have led the mobile money services revolution in East Africa. 


\subsection{Mobile Money}

Mobile money is a service for transferring money that is mobile phone-based [15]. It uses IT tools and channels that are non-banking for extending financial services to subscribers who cannot be reached by banks [15]. Mobile money services accelerate the speed of money transfer as funds move in electronic instead of the physical form [23]. To transfer money, a mobile phone user registers with a mobile money agent and then deposits cash [6]. This cash is shown as e-money in an e-wallet on the sender's SIM card [23]. The e-money can be sent to the receiver's phone. The e-money balance can be converted back into cash by the receiver on visiting an agent [23].

\subsection{Mobile Money Adoption in East Africa}

The best example of mobile money in East Africa is M-Pesa in Kenya, which was launched in 2007 by Safaricom [23]. Mobile money has helped bring 194,000 Kenyans out of poverty [1]. In 2008, Vodacom launched M-Pesa while Zantel launched Z-Pesa in Tanzania [19]. MTN mobile money in Uganda was launched in 2009 with at least 1000 users. Since its launch, several other players like Airtel money, M-cash, Ezee-money, M-Sente and Orange money have also joined the Ugandan market [19]. Micropay is the latest entrant to the Ugandan mobile money market, bringing the number of service providers to seven [24]. This has increased the number of registered mobile money users to at least 21.6 million [24].

Mobile money is already providing a partial substitute for bank retail services payments and could challenge banks' dominance in other services like deposits [17]. Ssonko and Tait [16] found mobile money to complement rather than substitute bank account ownership. Currently, it enables users to carry out the following services: Western Union money transfer; utility bill payments; tax remittances; fuel payments at petrol stations; school fees payments; bulk salary payments; mobile phone-based Treasury bonds; and mobile money loans [5]. Transfers across borders using M-Pesa hit 17 billion Kenya shillings ever since the service was introduced [25]. Kenya rolled out the mobile phone-based T-bond - the M-Akiba bond-through the mobile money platform [26]. Mobile money loans are in the form of M-Shwari in Kenya, M-Pawa in Tanzania and MoKash in Uganda. Rwanda uses Tigo Cash, MTN mobile money and Airtel money. The adoption of mobile money has resulted in economic activities and labor demand which have created employment opportunities in East Africa [2]. This has contributed to the Sustainable Development Goals.

The literature associated with mobile banking offers valuable insight into mobile money adoption because in both cases users face e-payment systems but there are some differences in the way customers perceive their value $[15,27]$. Kim et al. [22] investigated factors influencing the acceptance of ICT applications like mobile money. Their results found trust and risk as important factors. Their study also provides ground for other constructs like attitude, perceived usefulness and self-efficacy, which influence mobile money adoption.

To explain mobile money adoption, we identified the determinant factors based on the diffusion of innovation model [28], Unified Theory of Acceptance and Use of Technology (UTAUT) [29], the Theory of Planned Behavior (TPB) [30] and the Technology Acceptance Model (TAM) [31]. Based on TPB, users' adoption of mobile money is explained by their intentions [15,32]. The intentions are a function of subjective norms, attitude and perceived behavioral control [30,33]. Mobile money user intention for transactional services is of practical and scientific interest. TAM has been praised over the years for its contribution towards the understanding of consumer behavior [34]. The model was studied because it was found that the factors determining adoption intention of m-payment and $\mathrm{m}$-banking are applicable to mobile money context [11]. According to Lu et al. [35], TAM is a powerful framework that explains the different factors that influence customers' behavioral intention to use mobile-based services. Extended TAM was used by Ssonko and Tait [16] in the mobile money services context in Uganda to determine the effect of mobile money adoption on financial inclusion. Chauhan [7] integrated trust in TAM to study how the poor citizens of India accept mobile money. Lee et al. [36] included perceived risk and trust in the TAM to establish their impact on behavioral intention. Their results 
found perceived usefulness and trust to affect behavioral intention, trust mediated the impact of perceived risk on behavioral intention. Therefore, we extend this study by examining the two factors (trust and risk) further.

\section{Conceptual Framework and Hypothesis Development}

To examine how trust and risk perceptions affect mobile money acceptance in Uganda, we developed a model as shown in Figure 1. The model was used because its constructs can be used to explain how trust and risk perceptions of e-money adopters affect their adoption behavior. In our model, we considered six constructs: performance expectancy, structural assurance, perceived risk, trust belief, self-efficacy and behavioral intention. Past studies have also used at least one of these constructs to study user adoption behavior $[13,15,21,29,36-41]$.

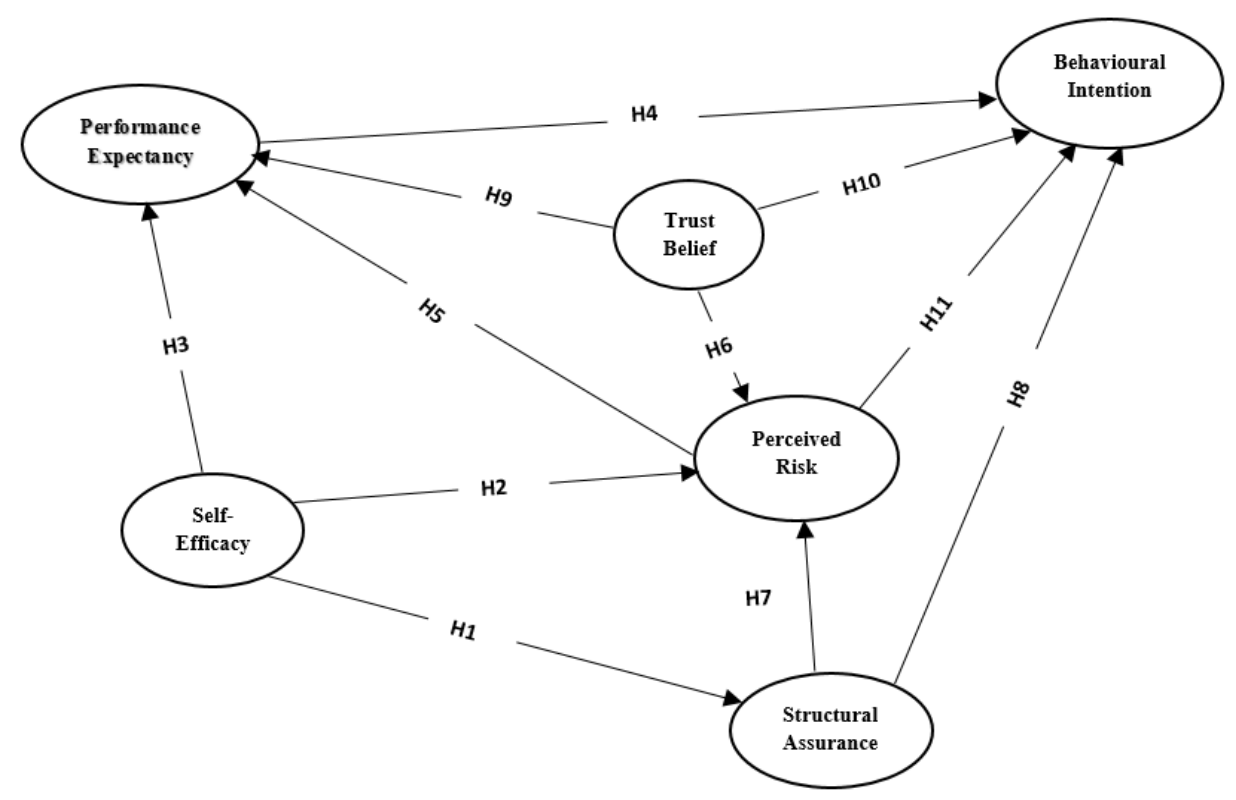

Figure 1. Research model.

\subsection{The Relevance of Trust in Mobile Money}

Even though a technology innovation may have many benefits, lack of trust in it can affect its use [7]. Trust in a mobile-based payment system depends on the amount of users' control, reliability, security and the reputation of the entity in charge of the system [42]. With the increasing threat of cybercrimes and the possibility of remotely hacking customers' phones $[9,43]$ trust is a vital factor in financial exchange relationships where there are unknown risks $[9,40]$. There is no guarantee that mobile money services providers will not take advantage of mobile money users. Therefore, mobile money users face this situation and can reduce their perceptions to risk by relying on trust [9]. The risk may emanate from the technical capability of telecommunication companies and the vulnerability of mobile money applications [44]. Some mobile money agents illegally hold money intended for money transfers [8]. Cases of mobile money fraud have increased recently, with some employees of telecommunication companies allegedly conniving to defraud their employers [45]. MTN Uganda lost billions to fraud on its mobile money platform [45].

\subsection{Meaning of Trust in Mobile Money}

Trust is the user's relative confidence in the mobile service [46]. It is the willingness by mobile money users to be vulnerable based on mobile money services providers' future behavior [47]. 
Based on McKnight and Chervany's [48] trust topology, we examine the dimensions of trust: structural assurance (SA) and trust belief (TB).

The trust perception about mobile money services providers refers to structural assurance [49]. Structural assurance helps to reduce mobile money users' perceived risk. Mobile money transactions are uncertain and vulnerable and therefore entail potential risk [50]. Trust belief is based on the perception that the mobile money services providers' trustworthiness consists of beliefs about competence, integrity and benevolence $[37,51]$. Trust is crucial because it reduces users' fears and worries about mobile money transactions $[9,50]$. Trust in mobile money encompasses three key dimensions: ability, benevolence and integrity [52]. Ability means that mobile money services providers possess the necessary experience and knowledge to fulfil their tasks [40] (p. 337). Integrity implies the mobile money services providers stick to their promises [40] (p. 337). Benevolence means the mobile money services providers are concerned about the interests of mobile money users and not only their expected benefits [40] (p. 337).

\subsection{Perceived Risk in Mobile Money}

Consumer adoption of mobile technologies is affected by security concerns and the possibility of remotely hacking customers' mobile phones [9,43]. Perceived risk is defined as a belief that unexpected events may occur [53]. It is the possibility that the mobile money user might incur financial losses or lose personal information as a result of using mobile transactions [46]. It measures beliefs of uncertainty about possible negative consequences [54]. Mobile money and internet banking are prone to similar risks [55]. The perceived risk of using mobile money is assumed to be larger than that of using internet banking [56]. The largest potential risk facing mobile money is probably an operational risk and central banks are concerned about its potential disruptive impact on the payments system [57]. Perceived risk has been found by past studies as a significant factor influencing adoption intention towards mobile payments $[37,39,58,59]$.

\subsection{Self-Efficacy and Mobile Money}

Self-efficacy is a person's belief in what they can do using their skills and capabilities, or how difficult or easy it would be to carry out a behavior [42]. It is the confidence that a mobile money user possesses in using mobile money application [46]. Duane et al. [42] discussed mobile self-efficacy (MSE), which measures users' confidence in mastering mobile applications. Our study focuses on establishing whether mobile money users have the ability and skills to execute mobile money services. Therefore, mobile money self-efficacy is the users' judgement of their capability to use mobile money application. Luo et al. [21] found self-efficacy to be positively related to structural assurance. Self-efficacy was found to have effects on mobile services adoption [60]. Therefore, potential mobile money users with high self-efficacy level will have high trust perception towards the mobile money services providers. We thus hypothesize that:

Hypothesis 1 (H1). Self-efficacy positively impacts structural assurance.

\subsection{Self-Efficacy and Perceived Risk in Mobile Money}

Mobile money requires some level of user competence to complete transactions successfully. Self-efficacy reduces the perceived risk in mobile money. The level of self-efficacy is directly related to the users' ability to execute mobile money transactions [61]. Mobile money users with a high self-efficacy level will anticipate lower loss from adverse circumstances such as transaction errors or mobile money fraud [21]. Therefore, we hypothesize that:

Hypothesis 2 (H2). Self-efficacy negatively impacts perceived risk in mobile money. 


\subsection{Performance Expectancy of Mobile Money}

The UTAUT model composed by Venkatesh et al. [29] integrates several constructs across competing models. Based on UTAUT, mobile money usage intention can be predicted by performance expectancy (PE), effort expectancy and social influence [14,29,62]. The degree of ease of use of mobile money application refers to effort expectancy [13]. The construct is similar TAM's perceived ease of use [59] (p. 862). Social influence is about the subjective influence of surrounding factors like friends' opinions on mobile money users' behavior [63]. The degree to which using mobile money application provides benefits to users to perform activities is referred to as performance expectancy $[14,29,41]$. This construct is similar to TAM's perceived usefulness [47]. A positive relationship exists between effort expectancy and performance expectancy [29]. When mobile money users feel that the application is easy to use, their expectation towards its performance increases. Several scholars researched and found that performance expectancy is positively related to behavioral intention $[13,14,21,29,62]$. Therefore, we hypothesize that:

Hypothesis 3 (H3). Self-efficacy is positively related to performance expectancy of mobile money.

Hypothesis 4 (H4). Performance expectancy positively impacts behavioral intention to adopt mobile money.

\subsection{Performance Expectancy and Perceived Risk of Mobile Money}

Performance expectancy refers to the users' understanding of the advantages that accrue from using technological innovations that result in better outcomes [64]. The extent mobile money users believe the innovation will help them attain their targets is part of their expectations about performance [65]. Therefore, performance expectancy is measured based on how useful mobile money users perceive the application to be in helping them to attain their job performance goals [29]. Perceived risk is negatively related to the performance expectancy of a new mobile money system [66]. Likely loss related to perceived risk exist in mobile money, which is beyond the control of mobile money users. Therefore, we hypothesize that:

Hypothesis 5 (H5). Perceived risk negatively impacts performance expectancy of mobile money.

\subsection{Trust Belief and Perceived Risk in Mobile Money}

Trust is an important factor which reduces users' perceived risk of transactions [67]. Therefore, it is considered as a mechanism for reducing perceived risk in mobile money. Trust belief is based on the perception that the mobile money services providers' trustworthiness consists of beliefs about competence, integrity and benevolence [37]. It helps in explaining how mobile money users overcome their perceived risk and engage in mobile transactions [68]. Lee et al. [36] found trust to mediate the impact of perceived risk on behavioral intention.

Potential mobile money users may not be sure of the technical capability of mobile money services providers to provide services. Trust belief towards mobile money services providers is relied on by the users to assess the potential risks involved in mobile money services [21]. Mobile money users who believe in the competence, benevolence and integrity of mobile money services providers are likely to overcome their risk perceptions towards mobile money [21]. Therefore, the stronger the trust a mobile money user has in mobile money services providers, the lower the risk they anticipate in adopting mobile money. We, therefore, hypothesize that:

Hypothesis 6 (H6). Trust belief will negatively impact perceived risk in mobile money.

\subsection{Structural Assurance, Perceived Risk and Behavioral Intention towards Mobile Money}

Structural assurance refers to the availability of legal structures, technological structures and other payment security measures to ensure that mobile money transactions are successfully completed by 
mobile money services providers [15,49]. Jack and Suri [69] emphasized risk sharing and transaction costs in the Kenyan mobile services context. McKnight et al. [40] researched about structural assurance as a form of institution-based trust which affects behavioral intention. Zhu and Chen [70] found trust as a key mediating variable in ensuring fairness of services and customer satisfaction in an online banking context. Zhou [71] emphasized that initial trust in mobile-based transactions can be ensured through structural assurance.

Mobile money transactions raise security concerns among users [8]. Just like trust belief, structural assurance helps to alleviate mobile money users' perceived risk. Mobile money services providers can draft customer services policies and promise customers to relay structural assurance information to mobile money users [21]. Mobile money users rely on the structural soundness of mobile money services providers and their ability to provide mobile money services with low perceived risk. Therefore, we posit that:

Hypothesis 7 (H7). Structural assurance is negatively related to perceived risk in mobile money.

Hypothesis 8 (H8). Structural assurance positively impacts behavioral intention towards mobile money.

\subsection{Performance Expectancy and Trust Belief in Mobile Money}

Perceived risk is negatively related to the performance expectancy of a mobile money system [66]. Trust belief mitigates this risk and enhances mobile money users' expected performance of mobile money [37]. In circumstances where mobile money services providers are unreliable, mobile money users may suffer losses. So, there is no incentive expected from using the services of mobile money services providers. The existing trust belief in mobile money services providers serves as a basis for potential mobile money users to anticipate whether the services can be conducted successfully and will be of benefit to them. Therefore, we posit that:

Hypothesis 9 (H9). Trust belief is positively related to performance expectancy of mobile money.

\subsection{Behavioral Intention and Trust/Risk Beliefs in Mobile Money}

Behavioral intention (BI) refers to a user's intentions to perform certain behaviors [72]. The construct was developed from the Theory of Planned Behavior (TPB) and Theory of Reasoned Action (TRA) and has been used in various technology acceptance studies [7,12,13,15,21,29,41]. Behavioral intention leads to actual behavior based on TRA [73]. Technology use is determined by behavioral intention and facilitating conditions based the UTAUT [29]. Trust and risk beliefs are important determinants of mobile money users' behavioral intention to conduct risky activities [21,40]. Mobile money users' willingness to engage in mobile money transactions depends on their level of trust $[58,67]$. Trust belief and risk beliefs significantly influence mobile money users' intention to release personal information via mobile transactions [21,74]. Trusting intentions refer to the mobile money users' willingness to depend on mobile money services providers [40] (p. 337). Trusting beliefs refer to the confident mobile money user perception that mobile money services providers have attributes beneficial to them [40] (p. 337). There exists an association between trusting intentions and trusting beliefs [40].

Mobile money users with favorable trust perceptions towards their mobile money services providers are likely to try the services [21]. Those whose risk beliefs towards mobile money is high will be skeptical for fear of losing their sensitive information or incurring losses and will be reluctant to try mobile money services [21]. Mobile money users' behavioral intention to adopt the service is therefore influenced by higher trust belief towards a mobile money services provider and lower risk perception towards mobile money. Therefore, we hypothesize as follows:

Hypothesis 10 (H10). Trust belief positively impacts behavioral intention to adopt mobile money. 
Hypothesis 11 (H11). Perceived risk is negatively related to behavioral intention to adopt mobile money.

\section{Research Methodology}

This research is built based on data from a survey of mobile money users in Uganda. We contacted 520 participants in a face-to-face interview by convenience sampling. The data were collected by the authors with the support of research assistants who were trained prior to going to the field. Participation was on a voluntary basis. Before each interview, study objectives were explained to participants. We promised respondents to treat collected data confidentially and only use it for research purposes. Respondents were requested for verbally informed consent to participate.

\subsection{Design of the Study and Sampling Distribution}

To examine the proposed model, we used a survey research methodology. A questionnaire was designed with a range of questions intended to measure the various constructs under study. A field survey was conducted by interviewing mobile money agents in Kampala, the capital city of Uganda, from 5 June to 30 June 2017. Kampala is the busiest and most populous district with the highest number of mobile money agents [16]. The estimated accessible population of Kampala is 1,578,133 people [16] (p.35). The suburbs of Kampala surveyed include; Nakawa, Nakasero, Ntinda, Bukoto, Kamwokya, Kyebando, Mulago, Wandegeya, Makerere, Mengo, Old Kampala, Kampala road, Garden city, Nakulabye, Bwaise and Kawempe.

The sample size for this study is based on the formula suggested by Nduneseokwu et al. [32] (p. 6);

$$
S=Z^{2} \times p \times 1-p /(\text { margin of error })^{2}
$$

where $S$ is the sample size, $Z$ is the $Z$ score at $95 \%$ level of confidence, $p$ is the standard deviation which is normally 0.5 , margin of error relates to confidence interval $( \pm 5 \%)$. As recommended by Nduneseokwu et al. [32], we determine the sample size for an infinite population at $Z=1.96$ and $95 \%$ confidence level, which results in 384 as sample size. Nduneseokwu et al. [32] further suggested an adjustment to the population $(1,578,133)$ of Kampala city, to obtain an adjusted population size by using the following formula:

$$
S_{\text {adjusted }}=(S) / \mathbf{1}+[(S-\mathbf{1}) / \text { population }]
$$

The results of the adjusted sample size suggest that we need a minimum of 384 valid responses. Ssonko and Tait [16] (p. 36) estimated the minimum sample size to be 400 valid responses for Kampala city.

The field survey was selected as the most effective way to gather perception data from Ugandan mobile money agents who are experienced in transacting using mobile money application because a large number of respondents could be reached and their responses collected. Nduneseokwu et al. [32] (p. 6) and Chuchird et al. [75] (p. 2) used field surveys for data collection. Also, because the level of internet connection in Uganda is still poor, the field survey was the most appropriate way of reaching respondents as compared to an online survey. A cross-sectional survey was used because of its advantages such as low cost involved in implementation as well as the relatively low demand placed on respondents [76].

The questionnaire consisted of two sections; demographic information and measures of variables under study. Out of the contacted 520 mobile money agents, 500 accepted to attempt our questionnaires. Registered mobile money agents operate small kiosks along the streets and in busy trading centers in the suburbs of Kampala. Explanations were done where the agents required clarifications. All the 500 questionnaires were received back from the respondents for examination [77] (p. 48). We used these respondents as a representative sample because they were legally registered and had the mobile money experience required for our study. 


\subsection{Measurement Development}

To ensure valid and reliable measures, the instruments used were based on past research and modified to suit mobile money research context. Three items of McKnight et al. [40] were used to measure structural assurance (SA). Three items of Gefen et al. [37] were used to measure trust belief (TB). Three items of Venkatesh et al. [29] were used to measure self-efficacy (SE). Performance expectancy (PE) was measured by three items [29]. Behavioral intention (BI) was measured using three items [29]. Perceived risk (PR) was measured using seven items developed for mobile money context with reference to Chen et al. [38], Featherman and Pavlou [66] and Jacoby and Kaplan [39]. Five-point Likert scales were applied in measuring all the constructs. Table 1 shows the resulting questionnaire items used for the study. A pre-test of all items was done with academic experts and graduate students to ensure that their meaning and understanding was clear. Five control variables for prediction intention towards mobile money services were included in the study. They are; age, gender, the level of education, mobile money usage experience and mobile money services provider preference.

\section{Data Analysis and Results}

\subsection{Descriptive Statistics}

Out of the 500 responses, we removed 62 invalid responses due to missing data, inconsistent answers and outliers [77] (p. 50). This resulted in 438 valid responses for analysis. Given that the minimum acceptable sample size is 384 valid responses, 438 valid responses represent an acceptable sample size. The sample descriptive statistics are as shown in Table 2. Of the 438 respondents: $53 \%$ were female and $47 \%$ were male; 276 were $18-30$ years old, 117 were $31-40$ years old while 81 were over 40 years of age. Among the entire respondents, $19 \%$ of them had mobile money experience of less than 1 year, while $62 \%$ had $1-5$ years and $18 \%$ had 6-10 years' experience. Of the respondents, $46 \%$ preferred using MTN mobile money, $43 \%$ preferred Airtel money, $4 \%$ preferred Orange money, $4 \%$ preferred Ezee-money, 2\% preferred M-Sente and 1\% preferred M-Cash. Further analysis of the level of education of respondents revealed that $8 \%$ had primary school education, $55 \%$ had secondary school education, $36 \%$ had University education and $1 \%$ were postgraduates. The sample is appropriate for testing the instruments as educated people are enthusiastic to adopt new mobile money technologies [41].

\subsection{Analysis of Results}

We used a two-step approach recommended by Anderson and Gerbing [78] for data analysis. Step one involves the measurement model analysis, while step two tests the structural relationships among latent constructs [78]. SmartPLS 2.0M3 (SmartPLS GmbH, Bönningstedt, Germany), a Structural Equation Modelling (SEM) application [79], helped in examining the testing of hypotheses, structural model and measurement model [33] (p. 10) because of the following reasons. Firstly, as suggested by Chin and Newsted [80], the PLS method places fewer restrictions on the measurement scales, residual distribution and sample size and is therefore suitable for our explorative study. Secondly, the data are non-normal in most consumer behavior studies and PLS is not bound by the normality assumption [81] that is required in covariance-based SEM [82]. Thirdly, the estimates of mediation effects provided by PLS are accurate and the approach accounts for measurement errors [83]. Fourthly, PLS allows the indicators to vary by contributing to the latent variables composite score and does not require equality of weights for all indicators [84]. Finally, PLS provides an alternative method to test theory [12,82]. 
Table 1. Questionnaire items used in the study.

\begin{tabular}{|c|c|c|c|c|}
\hline Construct & Item Code & Survey Statement & Likert Scale & Source \\
\hline \multirow{3}{*}{ Structural assurance (SA) } & SA1 & $\begin{array}{l}\text { MM has enough safeguards to make me feel comfortable using it to } \\
\text { transact personal business. }\end{array}$ & $\begin{array}{l}\text { Strongly Disagree/ } \\
\text { Strongly Agree }\end{array}$ & \multirow{3}{*}{ McKnight et al. [40] } \\
\hline & SA2 & $\begin{array}{l}\text { I feel assured of the legal and technological structure of MM to } \\
\text { protect me from financial losses. }\end{array}$ & & \\
\hline & SA3 & $\begin{array}{l}\text { I feel confident that encryption and other technological advances of } \\
\text { MM make it safe for me to do business there. }\end{array}$ & & \\
\hline \multirow{3}{*}{ Trust belief (TB) } & TB1 & $\begin{array}{l}\text { Based on my experience with MM service providers in the past, } \\
\text { I know they are honest. }\end{array}$ & $\begin{array}{l}\text { Strongly Disagree/ } \\
\text { Strongly Agree }\end{array}$ & \multirow{3}{*}{ Gefen et al. [37] } \\
\hline & TB2 & $\begin{array}{l}\text { Based on my experience with MM service providers in the past, } \\
\text { I know they care about customers. }\end{array}$ & & \\
\hline & TB3 & $\begin{array}{l}\text { Based on my experience with MM service providers in the past, } \\
\text { I know they are not opportunistic. }\end{array}$ & & \\
\hline \multirow{3}{*}{ Self-efficacy (SE) } & SE1 & $\begin{array}{l}\text { I could complete a job or task using MM application if there was no } \\
\text { one around to tell me what to do. }\end{array}$ & $\begin{array}{l}\text { Strongly Disagree/ } \\
\text { Strongly Agree }\end{array}$ & \multirow{3}{*}{ Venkatesh et al. [29] } \\
\hline & SE2 & $\begin{array}{l}\text { I could complete a job or task using MM application if I could call } \\
\text { someone for help if I got stuck. }\end{array}$ & & \\
\hline & SE3 & $\begin{array}{l}\text { I could complete a job using MM application if I had a lot of time to } \\
\text { complete the task for which the application was provided. }\end{array}$ & & \\
\hline \multirow{3}{*}{ Performance expectancy (PE) } & PE1 & Using MM enables me to accomplish tasks more quickly. & $\begin{array}{l}\text { Strongly Disagree/ } \\
\text { Strongly Agree }\end{array}$ & \multirow{3}{*}{ Venkatesh et al. [29] } \\
\hline & PE2 & Using MM increases my productivity. & & \\
\hline & PE3 & If I use MM, I will increase my chances of getting a pay rise. & & \\
\hline \multirow{3}{*}{ Behavioral intention (BI) } & BI1 & I intend to use MM in the next 3 months. & $\begin{array}{l}\text { Strongly Disagree/ } \\
\text { Strongly Agree }\end{array}$ & \multirow{3}{*}{ Venkatesh et al. [29] } \\
\hline & BI2 & I predict I would use MM in the next 6 months. & & \\
\hline & $\mathrm{BI} 3$ & I plan to use $\mathrm{MM}$ in the next 12 months. & & \\
\hline
\end{tabular}


Table 1. Cont.

\begin{tabular}{|c|c|c|c|c|}
\hline Construct & Item Code & Survey Statement & Likert Scale & Source \\
\hline \multirow{7}{*}{ Perceived risk (PR) } & PR1 & What are the chances that you stand to lose money if you use MM? & Low/high chance & \multirow{7}{*}{$\begin{array}{l}\text { Chen et al. [38]; } \\
\text { Featherman and } \\
\text { Pavlou [66]; Jacoby } \\
\text { and Kaplan [39] }\end{array}$} \\
\hline & PR2 & $\begin{array}{l}\text { What is the likelihood that there will be something wrong with the } \\
\text { performance of MM? }\end{array}$ & Low/high risk & \\
\hline & PR3 & $\begin{array}{l}\text { What are the chances that using MM will cause you to lose control } \\
\text { over the privacy of your payment information? }\end{array}$ & Improbable/probable & \\
\hline & PR4 & $\begin{array}{l}\text { Usage of MM would lead to a psychological loss for me because it } \\
\text { would not fit in well with my self-image or self-concept }\end{array}$ & Improbable/probable & \\
\hline & PR5 & $\begin{array}{l}\text { What are the chances that using MM will negatively affect the way } \\
\text { others think of you? }\end{array}$ & Low/high risk & \\
\hline & PR6 & $\begin{array}{l}\text { If you had begun to use MM, what are the chances that you will lose } \\
\text { time due to having to switch to a different payment method like } \\
\text { using Banks? }\end{array}$ & Low/high loss & \\
\hline & PR7 & $\begin{array}{l}\text { On the whole, considering all sorts of factors combined, about how } \\
\text { risky would you say it would be to sign up for and use MM? }\end{array}$ & Not risky at all/very risky & \\
\hline
\end{tabular}


Table 2. Respondent demographic profile.

\begin{tabular}{llcc}
\hline \multicolumn{1}{c}{ Measure } & \multicolumn{1}{c}{ Items } & Frequency & Percentage \\
\hline \multirow{2}{*}{ Gender } & Male & 208 & 47.49 \\
& Female & 230 & 52.51 \\
\hline \multirow{3}{*}{ Age } & $18-30$ & 276 & 63.01 \\
& $31-40$ & 117 & 26.71 \\
& $41-50$ & 40 & 9.13 \\
& $51-60$ & 5 & 1.14 \\
\hline \multirow{3}{*}{ Mobile Money experience } & Less than 1 year & 84 & 19.18 \\
& $1-5$ years & 273 & 62.33 \\
& 6-10 years & 77 & 17.58 \\
& More than 10 years & 4 & 0.91 \\
\hline \multirow{3}{*}{ MM Service provider preference } & Airtel Money & 188 & 42.92 \\
& Orange Money & 16 & 3.65 \\
& MTN Mobile Money & 203 & 46.35 \\
& M-Sente & 11 & 2.51 \\
& Ezee-Money & 16 & 3.65 \\
& M-Cash & 4 & 0.91 \\
\hline \multirow{3}{*}{ Level of Education } & Primary School & 34 & 7.76 \\
& Secondary School & 241 & 55.02 \\
& University Degree & 157 & 35.84 \\
& Postgraduate (Masters) & 6 & 1.37 \\
\hline
\end{tabular}

\subsection{Measurement Model}

\subsubsection{Reliability}

Measurement model assessment was done using reliability, which involves indicator reliability and internal consistency reliability [42]. The internal consistency reliability was tested using composite reliability (CR) values. All the values in the second column of Table 3 are greater than 0.7, which satisfies Bagozzi and Yi's [85] commonly acceptable level. The indicators individual reliability is based on the fact that latent variable variance explains at least $50 \%$ of the indicator [42]. Loadings of the manifest variable should be 0.7 or higher [86]. From Table 4 , the magnitude of all indicators is 0.7 or more as required. We, therefore, concluded that all indicators are reliable based on the two tests.

Table 3. Reliability and inter-construct correlations.

\begin{tabular}{lcccccccc}
\hline \multicolumn{1}{c}{ Constructs } & CR & AVE & BI & PE & PR & SA & SE & TB \\
\hline Behavioral Intention (BI) & 0.9130 & 0.7793 & 0.8828 & & & & & \\
Performance Expectancy (PE) & 0.8606 & 0.6737 & 0.3926 & 0.8208 & & & & \\
Perceived Risk (PR) & 0.7675 & 0.5241 & -0.3009 & -0.2026 & 0.7239 & & & \\
Structural Assurance (SA) & 0.8713 & 0.6939 & 0.1815 & 0.1470 & -0.1845 & 0.8330 & & \\
Self-Efficacy (SE) & 0.7476 & 0.6012 & -0.1269 & -0.2049 & -0.0904 & -0.0987 & 0.7754 & \\
Trust Belief (TB) & 0.8629 & 0.7601 & 0.0328 & -0.1047 & -0.2221 & 0.2585 & 0.2449 & 0.8718 \\
\hline
\end{tabular}

Note: Values on the diagonal represent the square root of the AVE of constructs.

Table 4. Matrix of loadings and cross-loadings.

\begin{tabular}{ccccccc}
\hline & BI & PE & PR & SA & SE & TB \\
\hline BI1 & 0.9215 & 0.3731 & -0.3150 & 0.2001 & -0.1493 & 0.0924 \\
BI2 & 0.9551 & 0.3802 & -0.2820 & 0.1841 & -0.1319 & 0.0240 \\
BI3 & 0.7592 & 0.2726 & -0.1782 & 0.0710 & -0.0302 & -0.0601 \\
PE1 & 0.2775 & 0.7581 & -0.0930 & 0.1413 & -0.2219 & -0.1805 \\
\hline
\end{tabular}


Table 4. Cont

\begin{tabular}{ccccccc}
\hline & BI & PE & PR & SA & SE & TB \\
\hline PE2 & 0.2956 & 0.8290 & -0.1563 & 0.1350 & -0.1333 & 0.0200 \\
PE3 & 0.3797 & 0.8712 & -0.2331 & 0.0947 & -0.1521 & -0.0883 \\
PR1 & -0.1945 & -0.1974 & 0.7016 & -0.2201 & 0.0433 & -0.0486 \\
PR2 & -0.2236 & -0.0656 & 0.7479 & -0.1407 & -0.1788 & -0.2548 \\
PR7 & -0.2342 & -0.1861 & 0.7216 & -0.0454 & -0.0464 & -0.1660 \\
SA1 & 0.0667 & 0.0144 & -0.1718 & 0.7503 & -0.0408 & 0.2962 \\
SA2 & 0.1271 & 0.0705 & -0.1725 & 0.8770 & -0.0909 & 0.2248 \\
SA3 & 0.2284 & 0.2373 & -0.1295 & 0.8659 & -0.1028 & 0.1607 \\
SE1 & -0.1588 & -0.2019 & -0.0163 & -0.1212 & 0.8720 & 0.2363 \\
SE2 & -0.0110 & -0.1008 & -0.1556 & -0.0120 & 0.6649 & 0.1281 \\
TB1 & 0.0871 & -0.0659 & -0.2474 & 0.2473 & 0.1542 & 0.9402 \\
TB2 & -0.0734 & -0.1412 & -0.1088 & 0.1985 & 0.3301 & 0.7976 \\
\hline
\end{tabular}

\subsubsection{Validity}

To examine the validity of reflective constructs, discriminant validity and convergent validity is used. Assessment of convergent validity is based on Average Variance Extracted (AVE) values as evaluation criterion [77]. As shown in the third column of Table 3, all AVE of constructs were 0.50 or more in line with the threshold suggested by Fornell and Larcker [87]. This indicates that convergent validity is sufficient, implying that each latent variable explained more than $50 \%$ of their indicator's variance on average. From Table 3, the square root of the AVE from each construct exceeds the correlation between the construct and other constructs in the model [80].

The patterns of the inter indicators of a construct with other constructs represent discriminant validity [42]. The examination of cross-factor loadings in Table 4 shows appropriate discriminant validity, as the loading of every indicator on the assigned construct exceeds its loading on other constructs [83]. Therefore, the discriminant validity of the research constructs is acceptable. SE3, TB3, PR3, PR4, PR5 and PR6 were eliminated from the analysis as their magnitude was found below 0.7 [81].

\subsection{Structural Model}

To assess the predictive performance of the structural model, we run PLS algorithm and obtained R-square values and path coefficients [79]. PLS together with the bootstrapping procedure are strong in prediction specification [81]. Research significance was assessed with 500, 1000 and 5000 bootstrap runs and similar results were obtained in all cases.

Structural path analysis results are as shown in Figure 2, significant relationships are shown by the bold lines while insignificant relationships or hypotheses not supported are shown by the dotted lines. The Table 5 and Figure 2 show the results of hypothesis testing. In Figure 2, $R^{2}$ values are shown within each construct. The model explains $10.2 \%$ of performance expectancy, $7 \%$ of the perceived risk and $21.3 \%$ of behavioral intention.

A $t$-test was adopted since all the hypotheses are clearly directional [81]. Bootstrapping was performed to compute t-statistics for each hypothesized relationship as shown in Table 5. To make the differences become very small, 5000 bootstrapping subsamples were used [39]. Most of the hypothesized relationships were significant, except for $\mathrm{H} 1, \mathrm{H} 2$ and $\mathrm{H} 10$. Based on path coefficients, H4 was most significant. This implies that during mobile money adoption, mobile money users rely on the performance expectancy of mobile money services with low perceived risk. Based on H11, perceived risk contributes significantly to users' behavioral intention to adopt mobile money. 


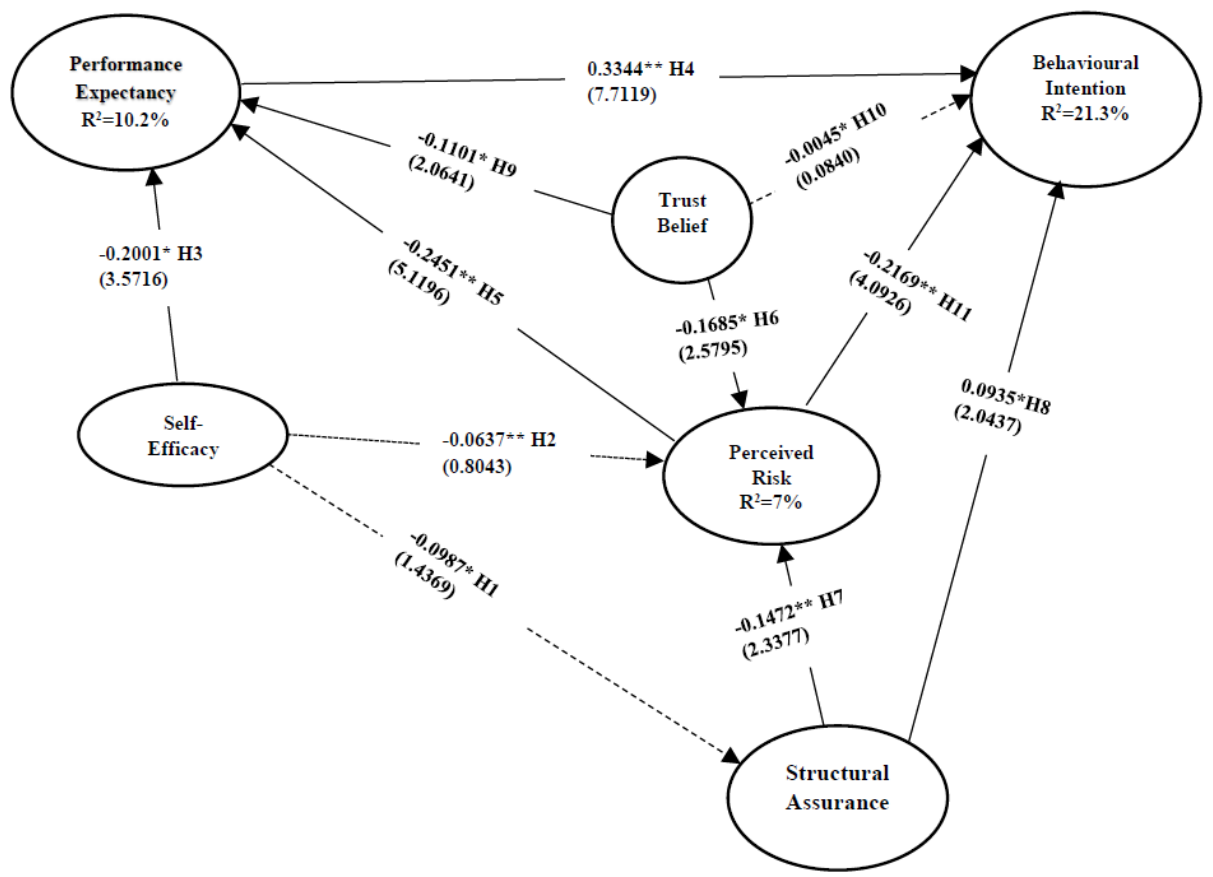

Notes: Broken lines show path coefficients that are not significant. $* \mathrm{P}<0.05, * * \mathrm{P}<0.01, * * * \mathrm{P}<0.001$

Figure 2. Results of PLS analysis.

Table 5. Summary of hypothesis testing results.

\begin{tabular}{|c|c|c|c|}
\hline Hypothesis & $\begin{array}{c}\text { Path } \\
\text { Coefficients }(\beta)\end{array}$ & $t$ Values & Conclusions \\
\hline $\begin{array}{l}\text { H1. Self-efficacy positively impacts } \\
\text { structural assurance. }\end{array}$ & -0.0987 & 1.4369 & $\begin{array}{c}p>0.05 \\
\text { (Not-supported) }\end{array}$ \\
\hline $\begin{array}{l}\text { H2. Self-efficacy negatively impacts perceived } \\
\text { risk in mobile money. }\end{array}$ & -0.0637 & 0.8043 & $\begin{array}{c}p>0.01 \\
\text { (Not-supported) }\end{array}$ \\
\hline $\begin{array}{l}\text { H3. Self-efficacy is positively related to } \\
\text { Performance expectancy of mobile money. }\end{array}$ & -0.2001 & 3.5716 & $\begin{array}{l}p<0.05 \\
\text { (Supported) }\end{array}$ \\
\hline $\begin{array}{l}\text { H4. Performance expectancy positively impacts } \\
\text { behavioral intention to adopt mobile money. }\end{array}$ & 0.3344 & 7.7119 & $\begin{array}{c}p<0.01 \\
\text { (Supported) }\end{array}$ \\
\hline $\begin{array}{l}\text { H5. Perceived risk negatively impacts } \\
\text { performance expectancy of mobile money. }\end{array}$ & -0.2451 & 5.1196 & $\begin{array}{c}p<0.01 \\
\text { (Supported) }\end{array}$ \\
\hline $\begin{array}{l}\text { H6. Trust belief will negatively impact } \\
\text { perceived risk in mobile money. }\end{array}$ & -0.1685 & 2.5795 & $\begin{array}{c}p<0.05 \\
\text { (Supported) }\end{array}$ \\
\hline $\begin{array}{l}\text { H7. Structural assurance is negatively related } \\
\text { to perceived risk in mobile money. }\end{array}$ & -0.1472 & 2.3377 & $\begin{array}{c}p<0.01 \\
\text { (Supported) }\end{array}$ \\
\hline $\begin{array}{l}\text { H8. Structural assurance positively impacts } \\
\text { behavioral intention towards mobile money. }\end{array}$ & 0.0935 & 2.0437 & $\begin{array}{c}p<0.05 \\
\text { (Supported) }\end{array}$ \\
\hline $\begin{array}{l}\text { H9. Trust belief is positively related to } \\
\text { performance expectancy of mobile money. }\end{array}$ & -0.1101 & 2.0641 & $\begin{array}{c}p<0.05 \\
\text { (Supported) }\end{array}$ \\
\hline $\begin{array}{l}\text { H10. Trust belief positively impacts behavioral } \\
\text { intention to adopt mobile money. }\end{array}$ & -0.0045 & 0.0840 & $\begin{array}{c}p>0.05 \\
\text { (Not-supported) }\end{array}$ \\
\hline $\begin{array}{l}\text { H11. Perceived risk is negatively related to } \\
\text { behavioral intention to adopt mobile money. }\end{array}$ & -0.2169 & 4.0926 & $\begin{array}{c}p<0.01 \\
\text { (Supported) }\end{array}$ \\
\hline
\end{tabular}

\section{Discussion}

The study was driven by the research question: How do trust and risk perceptions of Ugandan mobile money users influence the sustainable adoption of mobile money? It advances the literature on adoption of mobile payments which contributes to the achievement of Sustainable Development Goals. 


\subsection{Findings}

H1 was not supported, implying that self-efficacy does not positively impact the structural assurance of mobile money services providers $(\beta=-0.0987, t=1.4369)$. Our study suggests that Ugandan mobile money users' ability to execute mobile money services is not positively related to the structural soundness of mobile money services providers.

$\mathrm{H} 2$ was not supported, suggesting that self-efficacy is not negatively related to mobile money users' perceived risk in mobile money $(\beta=-0.0637, t=0.8043)$. Therefore, self-efficacy may not help mobile money users to overcome their perceived risk associated with mobile money. This is in agreement with Luo et al. [21], who came to similar findings in the case mobile banking services. Although Ugandan mobile money users may have the necessary skill to execute mobile money transaction (H3), this does not affect their perceived risk toward mobile money services.

$\mathrm{H} 3$ was supported, implying that self-efficacy is positively related to the performance expectancy of mobile money ( $\beta=-0.2001, t=3.5716$ ). Therefore, mobile money requires some level of user competence to complete transactions successfully. Our study recommends that Ugandan mobile money users may have the required ability, knowledge and skills to adopt mobile money services. Users' ability to carry out mobile money services may affect their performance expectancy. We advise mobile money services providers to build users' self-efficacy through providing trainings, operational manuals and videos guidance.

H4 was supported, meaning that performance expectancy of mobile money can be perceived by Ugandan mobile money users as the most important factor for mobile money acceptance $(\beta=0.3344, t=7.7119)$. This finding is consistent with previous literature $[13,14,21,29,62]$. Our study suggests the appropriateness of employing performance expectancy in studying new innovative technology acceptance. We advise mobile money services providers to make efforts on spreading the massage of importance of mobile money to its users and potential users. This could be achieved through a focused marketing strategy and mobile money user education of the applications.

$\mathrm{H} 5$ was supported, indicating that perceived risk can be negatively related to the performance expectancy of mobile money $(\beta=-0.2451, t=5.1196)$. This shows that Ugandan mobile money users' perceived risk in mobile money can lower their expected benefits from using it. Our study provides further support to Luo et al. [21] who came to similar findings on new innovative technology applications. We advise mobile money services providers to emphasize risk reduction strategies in a bid to increase users' performance expectancy of mobile money which results in mass adoption.

H6 was supported, implying that trust belief towards mobile money services providers is negatively related to the perceived risk in mobile money $(\beta=-0.1685, t=2.5795)$. Therefore, due to the uncertainties in mobile money, the strong trust Ugandan mobile money users have towards a mobile money services provider can lower the risk they anticipate in adopting mobile money. We advise mobile money services providers to build and maintain good trust belief. This motivates potential users to see mobile money application as a less risky platform for transacting which results into adoption of the services.

H7 was supported, suggesting that structural assurance is negatively related to the perceived risk in mobile money ( $\beta=-0.1472, t=2.3377)$. Structural assurance helps to alleviate the users' perceived risk of mobile money application. Ugandan mobile money users rely on the structural soundness of mobile money services providers and their ability to provide mobile money services with low perceived risk. We advise mobile money services providers to avail the necessary legal and technological structures and other payment security measures to ensure that transactions are successfully completed as doing so reduces the perceived risk of mobile money, which then results in adoption intention.

H8 was supported, advising that structural assurance is positively related to the behavioral intention to adopt mobile money ( $\beta=0.0935, t=2.0437$ ). This finding extends more support to past studies that concluded the same $[15,40]$. Therefore, mobile money services providers must establish 
appropriate legal and technological structures and efficient payment security measures to ensure the success of mobile money transactions.

H9 was supported that trust belief can be positively related to the performance expectancy of mobile money $(\beta=-0.1101, t=2.0641)$. Therefore, the existing trust belief in mobile money services providers can serve as the basis for potential users to anticipate whether the mobile money services can be successfully conducted and will be of any benefit to them. We advise mobile money services providers to build trust belief by maintain a high level of integrity, ensure honesty in all their transactions and avoid actions that cause public distrust.

H10 was not supported that trust belief may not be positively related to the users' behavioral intention to adopt mobile money $(\beta=-0.0045, t=0.0840)$. This implies that the likelihood of taking up the mobile money services on offer does not necessarily depend on the existing trust belief towards the mobile money services providers. Our study therefore suggests that trust belief is not directly related to mobile money behavioral intention but mitigates perceived risk (H6) and enhances users' expected performance of mobile money (H9). This study reveals that trust belief can be a key mediating construct for studying mobile money technology adoption.

H11 was supported that perceived risk is a significant determining factor for mobile money adoption $(\beta=-0.2169, t=4.0926)$. This finding suggests that perceived risk can reduce potential users' behavioral intention to adopt mobile money, which means that users are concerned about the vulnerabilities they face while using the application. Given the increased rates of fraud and hacking [8], they are skeptical about using the services. Our study therefore reveals that perceived risk is a key factor for studying mobile money technology acceptance. We advise mobile money services providers to adopt strategies for reducing perceived risk perceptions. For example, they could reduce perceived risk by having a financial loss protection policy and anti-fraud protection policy. They can also provide a customer satisfaction guarantee to reduce operational risk.

\subsection{Theoretical Contribution}

After examining trust and risk in the adoption of mobile money in Uganda, this study can contribute to the literature in following ways. First, this paper extends the theoretical knowledge of mobile money adoption by adapting a TAM model with users' trust and risk perceptions. We suggest a conceptual model for examining mobile money users' trust and risk perceptions and reveal several constructs which have not been previously applied in mobile money adoption studies. We empirically test how these constructs influence users' decision to adopt mobile banking, e-commerce and mobile payments. Most of these constructs have previously not been used in studies focusing on mobile money adoption. To our best knowledge, no empirical study has previously been conducted to focus on mobile money users' risk and trust perceptions in Uganda. Similar models were examined in Ghana [11] and India [7]. Thus, our study contributes to mobile money literature by showing that trust does not directly affect behavioral intention but it mediates the effects of perceived risk and performance expectancy which directly influence behavioral intention.

Second, our study contributes to the literature by showing how to apply personal trait factors (i.e., self-efficacy and structural assurance) to study mobile money adoption in Uganda, which has not been done before. This study is also the first to investigate multi-dimensional trust in the Ugandan mobile money context as shown by the analysis of structural assurance and trust belief.

\subsection{Implications for Research}

Several implications for mobile money adoption research in Uganda could be generated from our study findings. Firstly, this study found that intention to adopt mobile money in Uganda can be driven by the performance expectancy, structural assurance and perceived risk of mobile money. The structural soundness of services providers in providing mobile money services may lower perceived risk. Therefore, due to the high perceived risk associated with mobile money, it is crucial to build the technical capability, integrity and benevolence of mobile money services providers to overcome 
risk perceptions. The results reveal the relevance of the adoption stage of mobile money services. During this early stage of mobile money adoption in Uganda, mobile money users' uncertainty about the underlying technology in mobile money is high. A personal trait factor such as self-efficacy is identified as a major determinant of perceived risk and indirectly influences the behavioral intention. Multi-dimensional trust may play various roles in mobile money adoption. Structural assurance or trust towards a mobile money platform can be a mechanism for overcoming the perceived risk of mobile money and directly impact behavioral intention, while trust belief can also directly impact behavioral intention. The findings of our research contribute to the understanding of Ugandan mobile money users' risk and trust perceptions which are useful for mobile money studies in East Africa at large. The constructs under this study may be applied in other countries like Kenya in M-Pesa context and Tanzania in Z-Pesa context, so as to further verify the understanding of trust and risk perception in mobile money in Africa.

Secondly, the study of mobile money adoption can be useful to central banks in relation to financial inclusion and improvement of the ability to transfer money, which are important to achieve sustainable development. Mobile money adoption, if well facilitated, can help central bank authorities to attain their target of reaching the unbanked rural populations in East Africa. Mobile money is very useful to the poor population due to low transaction costs, the safety of money and processing speed [7]. Its success will be dictated by the rate of its sustainable adoption. Therefore, according to our study, central banks are recommended to continue to design mobile money regulations that do not stifle the valuable innovation. They may promote public policies such as mobile money customer protection. This will help customers overcome their perceived risk of mobile money and encourage a sense of security. We, therefore, advise central banks to encourage more research studies on mobile money adoption and financial inclusion.

Lastly, our study shows that $7 \%$ of the predictive power of the model is explained by perceived risk, which is large in comparison to other constructs under study. Central banks may not be able to regulate this mobile money risk, as it emanates from telecommunication companies' IT systems. However, they can work in partnership with communications regulators to ensure that their prudential priorities are met [44]. The few studies on mobile money adoption have focused on the TAM variables, this has created a need for more research on perceived risk in mobile money. We, therefore, suggest future research to explore this area.

\subsection{Implications for Practice}

We may offer useful practical implications for managers in telecommunications companies offering mobile money services in Uganda. Firstly, we suggest that the performance expectancy of mobile money is an important factor in adoption intention. Thus, to encourage the mobile money adoption, mobile money services providers may show the benefits of using mobile money to potential customers. Increased user education of MoKash, mobile money apps used in smartphones and mobile money Western Union transfers should be able to facilitate adoption intention.

Secondly, during the adoption of mobile money services, users may have some ideas about the benefits of technology application as a medium for transactions. Based on this study, the significance of structural assurance may imply that an effective strategy towards helping Ugandan users to reduce their mobile money risk perceptions is to increase their education about the mobile money application and its security features.

Thirdly, perceived risk is a significant factor in mobile money adoption. By modelling perceived risk with other indicators, the research shows several risk considerations that can affect the adoption of mobile money services in Uganda. If mobile money services providers launch the services, they may emphasize measures to counter those risk perceptions: for example, they could provide a customer satisfaction guarantee for reducing the customer's operational risk.

Fourthly, public policy issues pertaining to consumer protection should be developed by government agents in order to ensure structural assurance, helping alleviate Ugandan users' perceived 
risk in the mobile money application. Central banks may regulate that mobile money services providers need to carry out proper disclosure of their terms and conditions, like transaction fees for customer access to financial services. A tight controlled regulatory policy focusing on transaction security and reduction of mobile money fraud cases may increase trust.

Fifthly, according to our study, $62 \%$ of the respondents had at least one mobile money transaction experience within the last five years. This implies that mobile money is in its infancy stage in Uganda. $63 \%$ of them were aged 18 to 30 years, which shows that the majority of Ugandan users are the youthful generation being ambitious to learn new technologies. Of the respondents, 55\% had a secondary school education while $36 \%$ had a university education, which implies that most Ugandan users were educated. Therefore, we advise mobile money service providers to target their services offerings towards the age group from 18 to 30 years and the educated users who are the potential customers. This information may be useful for companies to develop an effective marketing strategy for mobile money adoption in Uganda.

Last but not least, mobile money has been used as a substitute for commercial bank deposits in Uganda. By looking at the findings from the commercial banks' perspective, executive officers may be able to know which variables they can manipulate to compete with mobile money. Therefore, when designing new banking services, they should be mindful of factors like customer perceived risk, structural assurance and trust. They may also need to continue partnering with mobile money services providers to realize synergetic benefits.

\section{Limitations and Future Research Directions}

This study countered limitations that create room for future research in the mobile money sector. Firstly, responses that were collected using a field study which may not fully represent the entire population. This could cause some bias towards the contacted population. Therefore, future research involving an online survey is encouraged to cover the opinions of those mobile money users who did not have access to the field survey. Secondly, the study was carried out in June 2017 using cross-sectional survey. Reliability can be improved by carrying out a longitudinal analysis of over a six month to one year period. This would cover various respondents' opinions over a longer period of time. Thirdly, we used a field survey questionnaire to collect the measures of the constructs under study at the same point in time. Some common method variance may exist. More research using methods that involves qualitative and quantitative approaches is encouraged. Fourthly, the data used for empirical analysis was collected from respondents in Uganda who have characteristics differing from subjects in other parts of the world. Future research could focus on the replication of a similar topic in another part of the world like Korea, Kenya, Tanzania and India. This would aid in the assessment of the validity of the proposed research model across different countries. Finally, other variables, like the added value of mobile payments, the attractiveness of alternatives, a disposition to trust, perceived ease of use, attitude, social influence, effort expectancy and innovativeness in new technologies, could be introduced into the model and tested to view results. This will improve the explanatory power of the model.

\section{Conclusions}

The purpose of this study was to examine how trust and risk perceptions influence on the acceptance of mobile money in Uganda. It is crucial to understand how to empower African people to use financial services for Sustainable Development Goals (SDGs) and mobile money is an enabler being promoted by many African countries. Such mobile money adoption helps financial inclusion of the unbanked and underbanked and its related economic activities can improve employment reducing poverty and facilitating sustainable economic development. However, there are very limited studies to understand how to encourage user participation in Africa. Thus, our study is conducted to measure mobile money user intention for transactional services in Uganda, which can be of practical and scientific interest in terms of sustainable development in Africa. Our study suggests that mobile 
money user intention is a function of performance expectancy, perceived risk and structural assurance. Personal trait factors like self-efficacy, trust belief and structural assurance can play a significant role in influencing consumers' perceptions toward mobile money acceptance.

The results suggest that perceptions towards mobile money adoption can help mobile money services providers, commercial banks and central banks to see how customers interact with mobile money technology, thereby enabling them to assess trust and reduce risk perceptions towards sustainable adoption. The findings may help mobile money services providers to come up with effective marketing strategies for encouraging customers to adopt mobile money applications. Commercial banks are advised to come up with counter-measures like a partnership with mobile money services providers so as to realize synergetic benefits. Central banks may need to improve their public policies like mobile money customer protection. We hope that the findings of this study can stimulate future research on the sustainable adoption of mobile money technologies.

Acknowledgments: This work was supported by the National Research Foundation of Korea Grant funded by the Korean Government (NRF-2014S1A5A8018136). We acknowledge the support from the Central Bank of Uganda. We thank the anonymous reviewers for their invaluable comments. The views expressed in this article are those of the authors and not necessarily the institutions affiliated with the study. The usual caveats apply.

Author Contributions: Ronald Baganzi and Antonio K.W. Lau designed and formulated the theoretical framework; designed the questionnaire, data analysis methods and analyzed the data. Ronald Baganzi and Antonio K.W. Lau wrote the paper. All authors contributed to reading and approving the final manuscript.

Conflicts of Interest: The authors declare no conflict of interest. The founding sponsors had no role in the design of the study; in the collection, analyses, or interpretation of data; in the writing of the manuscript and in the decision to publish the results.

\section{References}

1. GSMA (Global System for Mobile Association). The Mobile Economy 2017; Global System for Mobile Association: London, UK, 2017.

2. Kikulwe, E.M.; Fischer, E.; Qaim, M. Mobile Money, Smallholder Farmers, and Household Welfare in Kenya. PLoS ONE 2014, 9, e109804. [CrossRef] [PubMed]

3. Firpo, J. E-Money-Mobile Money-Mobile Banking-What's the Difference? Available online: http: / / blogs.worldbank.org/psd/e-money-mobile-money-mobile-banking-what-s-the-difference (accessed on 30 June 2017).

4. Mugambi, A.; Njunge, C.; Yang, S.C. Mobile-Money Benefits and Usage: The Case of M-PESA. IT Prof. 2014, 16, 16-21. [CrossRef]

5. Bank of Uganda. Bank of Uganda Annual Report FY 2015/2016; Bank of Uganda: Kampala, Uganda, 2015.

6. Bisht, S.S.; Mishra, V. ICT-Driven Financial Inclusion Initiatives for Urban Poor in Developing Economy: Implications for Public Policy. Behav. Inf. Technol. 2016, 35, 817-832. [CrossRef]

7. Chauhan, S. Acceptance of Mobile Money by Poor Citizens of India: Integrating Trust into the Technology Acceptance Model. Info 2015, 17, 58-68. [CrossRef]

8. Kasekende, L. Bank of Uganda's Role in Monetary Policy, Regulation and Financial Sector Development; Bank of Uganda: Kampala, Uganda, 2014.

9. Malaquias, R.F.; Hwang, Y.-J. An Empirical Study on Trust in Mobile Banking: A Developing Country Perspective. Comput. Hum. Behav. 2016, 54, 453-461. [CrossRef]

10. Njoroge, P. Financial Inclusion in Sub-Saharan Africa; Central Bankers' Speeches; Central Bank of Kenya: Nairobi, Kenya, 2016.

11. Tobbin, P.; Kuwornu, J.K.M. Adoption of Mobile Money Transfer Technology: Structural Equation Modeling Approach. Eur. J. Bus. Manag. 2011, 3, 59-78.

12. Adapa, S.; Roy, S.K. Consumers' Post-Adoption Behaviour towards Internet Banking: Empirical Evidence from Australia. Behav. Inf. Technol. 2017, 36, 1-14. [CrossRef]

13. Al-Gahtani, S.S.; Hubona, G.S.; Wang, J. Information Technology (IT) in Saudi Arabia: Culture and the Acceptance and Use of IT. Inf. Manag. 2007, 44, 681-691. [CrossRef]

14. Venkatesh, V.; Thong, J.; Xu, X. Consumer Acceptance and User of Information Technology: Extending the Unified Theory of Acceptance and Use of Technology. MIS Q. 2012, 36, 157-178. 
15. Upadhyay, P.; Jahanyan, S. Analyzing User Perspective on the Factors Affecting Use Intention of Mobile-Based Transfer Payment. Internet Res. 2016, 26, 38-56. [CrossRef]

16. Ssonko, G.W.; Tait, M. Effect of Mobile Money on Financial Inclusion. In Proceedings of the Southern African Institute of Management Scientists (SAIMS) Conference, Bloemfontein, South Africa, 10-12 September 2017; pp. 30-59.

17. Mutebile, E.T. Mobile Money and the Economy; Central Bankers' Speeches; Bank for International Settlements: Kampala, Uganda, 2015.

18. Mutebile, E.T. Bank of Uganda's 50th Anniversary; Central Bankers' Speeches; Bank for International Settlements: Kampala, Uganda, 2016.

19. Nampewo, D.; Tinyinondi, G.A.; Kawooya, D.R.; Ssonko, G.W. Determinants of Private Sector Credit in Uganda: The Role of Mobile Money. Financ. Innov. 2016, 2, 1-16. [CrossRef]

20. Kasekende, L. Improving Financial Literacy in Uganda; Central Bankers' Speeches; Bank for International Settlements: Kampala, Uganda, 2015.

21. Luo, X.; Li, H.; Zhang, J.; Shim, J.P. Examining Multi-Dimensional Trust and Multi-Faceted Risk in Initial Acceptance of Emerging Technologies: An Empirical Study of Mobile Banking Services. Decis. Support Syst. 2010, 49, 222-234. [CrossRef]

22. Kim, D.J.; Ferrin, D.L.; Rao, H.R. A Trust-Based Consumer Decision-Making Model in Electronic Commerce: The Role of Trust, Perceived Risk, and Their Antecedents. Decis. Support Syst. 2008, 44, 544-564. [CrossRef]

23. Morawczynski, O. Exploring the Usage and Impact of "transformational" mobile Financial Services: The Case of M-PESA in Kenya. J. East. Afr. Stud. 2009, 3, 509-525. [CrossRef]

24. Bank of Uganda. Bank of Uganda Annual Supervision Report; Bank of Uganda: Kampala, Uganda, 2016.

25. Okuttah, M. Safaricom M-Pesa Transfers across Borders Hit Sh17bn. Business Daily, 4 January 2016.

26. Nwaniki, C. Kenya Plans March Rollout of Mobile Phone-Based T-Bond. Business Daily, 11 January 2016.

27. Laukkanen, T. Internet vs. Mobile Banking: Comparing Customer Value Perceptions. Bus. Process Manag. J. 2007, 13, 788-797. [CrossRef]

28. Rogers, E.M. Diffusion of Innovations; Free Press: Glencoe, UK, 1962.

29. Venkatesh, V.; Morris, M.G.; Davis, G.B.; Davis, F.D. User Acceptance of Information Technology: Toward a Unified View. MIS Q. 2003, 27, 425-478. [CrossRef]

30. Ajzen, I.; Fishbein, M. Understanding Attitudes \& Predicting Social Behavior; Prentice Hall: Sydney, Australia, 1985.

31. Davis, F.D. Perceived Usefulness, Perceived Ease of Use, and User Acceptance of Information Technology. MIS Q. 1989, 13, 319-340. [CrossRef]

32. Nduneseokwu, C.K.; Qu, Y.; Appolloni, A. Factors Influencing Consumers' Intentions to Participate in a Formal E-Waste Collection System: A Case Study of Onitsha, Nigeria. Sustainability 2017, 9, 881. [CrossRef]

33. Chung, N.-H.; Koo, C.-M.; Lee, K.-M. Assessing the Impact of Mobile Technology on Exhibition Attendees' Unplanned Booth Visit Behaviour. Sustainability 2017, 9, 884. [CrossRef]

34. Tobbin, P. The Adoption of Transformational Mobile Banking by the Unbanked. Digiworld Econ. J. 2012, 86, 103-223.

35. Lu, J.; Yu, C.-S.; Liu, C.; Yao, J.E. Technology Acceptance Model for Wireless Internet. J. Internet Res. 2003, 13, 206-222. [CrossRef]

36. Lee, K.-S.; Lee, H.-S.; Kim, S.-Y. Factors Influencing the Adoption Behavior of Mobile Banking: A South Korean Perspective. J. Internet Bank. Commer. 2007, 12, 92-114.

37. Gefen, D.; Karahanna, E.; Straub, D.W. Trust and TAM in Online Shopping: An Integrated Model. MIS Q. 2003, 27, 51-90. [CrossRef]

38. Chen, Y.; Yan, X.; Fan, W.; Gordon, M. The Joint Moderating Role of Trust Propensity and Gender on Consumers' Online Shopping Behavior. Comput. Hum. Behav. 2015, 43, 272-283. [CrossRef]

39. Jacoby, J.; Kaplan, L.B. The Components of Perceived Risk. Adv. Consum. Res. 1972, 3, 382-393.

40. McKnight, D.H.; Choudhury, V.; Kacmar, C. Developing and Validating Trust Measures for E-Commerce: An Integrative Typology. Inf. Syst. Res. 2002, 13, 334-359. [CrossRef]

41. Oliveira, T.; Thomas, M.; Baptista, G.; Campos, F. Mobile Payment: Understanding the Determinants of Customer Adoption and Intention to Recommend the Technology. Comput. Hum. Behav. 2016, 61, 404-414. [CrossRef]

42. Duane, A.; O'Reilly, P.; Andreev, P. Realising M-Payments: Modelling Consumers' Willingness to M-Pay Using Smart Phones. Behav. Inf. Technol. 2014, 33, 318-334. [CrossRef] 
43. Federal Reserve Bank. Current Use of Mobile Banking and Payments. Available online: https:// www.federalreserve.gov/econresdata/mobile-devices/2012-current-use-mobile-banking-payments.htm (accessed on 30 June 2017).

44. Kasekende, L. Mobile Money Services-Talking Points. Available online: http:/ /nyucted.org/wp-content/ uploads/2012/11/louis-kasekende-mobile-money-uganda2.pdf (accessed on 7 April 2017).

45. Morawczynski, O. Fraud in Uganda: How Millions Were Lost to Internal Collusion. Available online: https: / / www.cgap.org/blog/fraud-uganda-how-millions-were-lost-internal-collusion (accessed on 30 June 2017).

46. Al-Jabri, I.M. The Intention to Use Mobile Banking: Further Evidence from Saudi Arabia. S. Afr. J. Bus. Manag. 2015, 46, 23-34.

47. Zhou, T. Understanding the Determinants of Mobile Payment Continuance Usage. Ind. Manag. Data Syst. 2014, 114, 936-948. [CrossRef]

48. McKnight, D.H.; Chervany, N.L. What Trust Means in E-Commerce Customer Relationships: An Interdisciplinary Conceptual Typology. Int. J. Electron. 2002, 6, 35-59. [CrossRef]

49. Zhou, T. An Empirical Examination of Initial Trust in Mobile Payment. Wirel. Pers. Commun. 2014, 77, 1519-1531. [CrossRef]

50. Lu, Y.; Yang, S.; Chau, P.Y.K.; Cao, Y. Dynamics between the Trust Transfer Process and Intention to Use Mobile Payment Services: A Cross-Environment Perspective. Inf. Manag. 2011, 48, 393-403. [CrossRef]

51. Park, J.-K.; Gunn, F.; Han, S.-L. Multidimensional Trust Building in E-Retailing: Cross-Cultural Differences in Trust Formation and Implications for Perceived Risk. J. Retail. Consum. Serv. 2012, 19, 304-312. [CrossRef]

52. Gefen, D.; Straub, D.W. Consumer Trust in B2C E-Commerce and the Importance of Social Presence: Experiments in E-Products and E-Services. Omega 2004, 32, 407-424. [CrossRef]

53. Lin, K.-M. Understanding Undergraduates' Problems from Determinants of Facebook Continuance Intention. Behav. Inf. Technol. 2016, 35, 693-705. [CrossRef]

54. Thakur, R.; Srivastava, M. Adoption Readiness, Personal Innovativeness, Perceived Risk and Usage Intention across Customer Groups for Mobile Payment Services in India. Internet Res. 2014, 24, 369-392. [CrossRef]

55. Lee, M.S.Y.; McGoldrick, P.J.; Keeling, K.A.; Doherty, J. Using ZMET to Explore Barriers to the Adoption of 3G Mobile Banking Services. Int. J. Retail Distrib. Manag. 2003, 31, 340-348. [CrossRef]

56. Nel, J.; Boshoff, C. The Impact of Cross-Channel Cognitive Evaluations on the Continued Use Intentions of Mobile Banking. Manag. Dyn. 2014, 23, 2-19.

57. Kasekende, L. What Role Does Financial Inclusion Play in the Policy Agenda for Inclusive Growth in Sub-Saharan Africa? Development 2014, 57, 481-487. [CrossRef]

58. Kim, K.K.; Prabhakar, B. Initial Trust, Perceived Risk, and the Adoption of Internet Banking. Proc. ICIS 2000, 1, 537-543.

59. Slade, E.L.; Dwivedi, Y.K.; Piercy, N.C.; Williams, M.D. Modeling Consumers' Adoption Intentions of Remote Mobile Payments in the United Kingdom: Extending UTAUT with Innovativeness, Risk, and Trust. Psychol. Mark. 2015, 32, 860-873. [CrossRef]

60. Yang, K. The Effects of Technology Self-Efficacy and Innovativeness on Consumer Mobile Data Service Adoption between American and Korean Consumers. J. Int. Consum. Mark. 2010, 22, 117-127. [CrossRef]

61. Faqih, K.M.S. Exploring the Influence of Perceived Risk and Internet Self-Efficacy on Consumer Online Shopping Intentions: Perspective of Technology Acceptance Model. Int. Manag. Rev. 2013, 9, 67-78.

62. Zhou, T. Examining Location-Based Services Usage From the Perspectives of Unified Theory of Acceptance and Use of Technology and Privacy Risk. J. Electron. Commer. Res. 2012, 13, 135-144.

63. López-Nicolás, C.; Molina-Castillo, F.J.; Bouwman, H. An Assessment of Advanced Mobile Services Acceptance: Contributions from TAM and Diffusion Theory Models. Inf. Manag. 2008, 45, 359-364. [CrossRef]

64. Zhou, T. Exploring Mobile User Acceptance Based on UTAUT and Contextual Offering. In Proceedings of the International Symposium on Electronic Commerce and Security, Guangzhou, China, 3-5 August 2008; pp. 241-245.

65. Chen, K.-Y.; Chang, M.-L. User Acceptance of "near Field Communication" Mobile Phone Service: An Investigation Based on the "Unified Theory of Acceptance and Use of Technology" Model. Serv. Ind. J. 2013, 33, 609-623. [CrossRef]

66. Featherman, M.S.; Pavlou, P.A. Predicting E-Services Adoption: A Perceived Risk Facets Perspective. Int. J. Hum. Comput. Stud. 2003, 59, 451-474. [CrossRef] 
67. Wang, E.S.-T.; Lin, R.-L. Perceived Quality Factors of Location-Based Apps on Trust, Perceived Privacy Risk, and Continuous Usage Intention. Behav. Inf. Technol. 2016, 36, 2-10. [CrossRef]

68. Jarvenpaa, S.; Tractinsky, N.; Saarinen, L. Consumer Trust in an Internet Store: A Cross-Cultural Validation. J. Comput. Commun. 1999, 5, 1-35. [CrossRef]

69. Jack, W.; Suri, T. Risk Sharing and Transactions Costs: Evidence from Kenya's Mobile Money Revolution. Am. Econ. Rev. 2014, 104, 183-223. [CrossRef]

70. Zhu, Y.; Chen, H. Service Fairness and Customer Satisfaction in Internet Banking. Internet Res. 2012, 22, 482-498. [CrossRef]

71. Zhou, T. An Empirical Examination of Initial Trust in Mobile Banking. Internet Res. 2011, 21, 527-540. [CrossRef]

72. Ajzen, I.; Fishbein, M. Belief, Attitude, Intention, and Behaviour: An Introduction to Theory and Research; Addison-Wesley: Reading, MA, USA, 1975.

73. Kwee-Meier, S.; Butzler, J.; Schlick, C. Development and Validation of a Technology Acceptance Model for Safety-Enhancing, Wearable Systems. Behav. Inf. Technol. 2016, 35, 394-409. [CrossRef]

74. Malhotra, N.K.; Kim, S.-S.; Agarwal, J. Internet Users' Information Privacy Concerns (IUIPC): The Construct, the Scale, and a Causal Model. Info Sys. Res. 2004, 15, 336-355. [CrossRef]

75. Chuchird, R.; Sasaki, N.; Abe, I. Influencing Factors of the Adoption of Agricultural Irrigation Technologies and the Economic Returns: A Case Study in Chaiyaphum Province, Thailand. Sustainability 2017, 9, 1524. [CrossRef]

76. Zikmund, W.G. Business Research Methods, 7th ed.; Thomson/South-Western: Cincinnati, OH, USA, 2003.

77. Hair, J.F.; Hult, G.T.M.; Ringle, C.M.; Sarstedt, M. A Primer on Partial Least Squares Structural Equation Modelling (PLS-SEM); SAGE Publications, Inc.: London, UK, 2014.

78. Anderson, J.; Gerbing, D. Structural Equation Modelling in Practice: A Review and Recommended Two-Step Approach. Psychol. Bull. 1988, 103, 411-423. [CrossRef]

79. Park, J.-Y.; Sung, C.-S.; Im, I. Does Social Media Use Influence Entrepreneurial Opportunity? A Review of Its Moderating Role. Sustainability 2017, 9, 1593. [CrossRef]

80. Chin, W.W.; Newsted, P.R. Structural Equation Modeling Analysis with Small Samples Using Partial Least Squares. In Statistical Strategies for Small Sample Research; Hoyle, R.H., Ed.; SAGE Publications, Inc.: Thousand Oaks, CA, USA, 1999.

81. Lu, J.; Wei, J.; Yu, C.-S.; Liu, C. How Do Post-Usage Factors and Espoused Cultural Values Impact Mobile Payment Continuation? Behav. Inf. Technol. 2016, 36, 140-164. [CrossRef]

82. Henseler, J.; Ringle, C.M.; Sinkovics, R.R. The Use of Partial Least Squares Path Modeling in International Marketing. Adv. Int. Mark. 2009, 20, 277-319.

83. Chin, W.W. The Partial Least Squares Approach for Structural Equation Modeling. In Modern Methods for Business Research; Marcoulides, G.A., Ed.; Lawrence Erlbaum Associates: Hillsdale, NJ, USA, 1998.

84. Hair, J.F.; Bill, B.; Barry, B.; Rolph, E.A. Multivariate Data Analysis; Pearson: Englewood Cliffs, NJ, USA, 2009.

85. Bagozzi, R.P.; Yi, Y.-J. On the Evaluation of Structural Equation Models. J. Acad. Mark. Sci. 1988, 16, 74-94. [CrossRef]

86. Gefen, D.; Straub, D.W.; Boudreau, M.-C. Structural Equation Modeling and Regression: Guidelines for Research and Practice. CAIS 2000, 4, 1-70.

87. Fornell, C.; Larcker, D.F. Evaluating Structural Equation Models with Unobservable Variables and Measurement Error. J. Mark. 1981, 1, 39-50. [CrossRef]

(C) 2017 by the authors. Licensee MDPI, Basel, Switzerland. This article is an open access article distributed under the terms and conditions of the Creative Commons Attribution (CC BY) license (http:/ / creativecommons.org/licenses/by/4.0/). 